\begin{tabular}{|c|c|c|c|}
\hline & \multicolumn{2}{|c|}{ RESEARCH ARTICLE $\quad$ ARAŞTIRMA MAKALESİ } & \\
\hline Title of Article & \multicolumn{2}{|c|}{$\begin{array}{c}\text { Investigation of Open-Green Areas in } \\
\text { Apartment Complexes and Housing } \\
\text { Development: } \\
\text { Isparta City Center Example }\end{array}$} & \\
\hline $\begin{array}{l}\text { Corresponding } \\
\text { Author }\end{array}$ & \multicolumn{2}{|c|}{$\begin{array}{l}\text { Candan KUŞ ŞAHİN } \\
\text { Süleyman Demirel Üniversitesi, Mimarlık Fakültesi, Peyzaj Mimarlığı Bölümü, Isparta } \\
\text { e-posta: candansahin@ @du.edu.tr }\end{array}$} & \\
\hline $\begin{array}{l}\text { Received Date } \\
\text { Accepted Date }\end{array}$ & \multicolumn{2}{|l|}{$\begin{array}{l}15.08 .2020 \\
14.10 .2020\end{array}$} & \\
\hline Author / Authors & $\begin{array}{l}\text { Candan KUŞ ŞAHİN } \\
\text { M. Atilla AŞKIN }\end{array}$ & $\begin{array}{l}\text { ORCID: 0000-0002-0413-2380 } \\
\text { ORCID: 0000-0002-1886-1939 }\end{array}$ & \\
\hline How to Cite & \multicolumn{2}{|c|}{$\begin{array}{l}\text { KUŞ ŞAHIN, C., AŞKIN, M. A., (2020). Toplu Konut ve Site Bahçelerindeki Açık ve } \\
\text { Yeşil Alanların İrdelenmesi: Isparta Kent Merkezi Örneği, Kent Akademisi, Volume, } \\
\text { 13, Issue 3, Pages, 460-474 }\end{array}$} & $\begin{array}{l}\text { Kent Akademisi } \\
\text { Urban Academy }\end{array}$ \\
\hline
\end{tabular}

\title{
Site ve Toplu Konut Bahçelerindeki Açık ve Yeşil Alanların İrdelenmesi: Isparta Kent Merkezi Örneği
}

\begin{abstract}
:
In this study; the apartment complexes and housing development in Isparta city center were examined in terms of open and green areas. In this context, structural elements, architectural design principles and planted materials have been evaluated under landscape architecture major. A standard questionnaire was prepared in advance and applied to the responders who are take care the gardens of apartment complex housing sites. Hence, a random sampling method have been applied with face-to-face survey technique in 23 neighborhoods of Isparta city. The answers of responders who take care of gardens were noted. As a result of these data collection, it was aimed to reveal opinions and tendencies on public housing gardens. However, the plant and structural materials were determined with carefully examination by evaluating density and intended use. It has realized that apartment complex housing is a new concept and only some neighborhoods has these kinds of settlements in Isparta city. Moreover, there is not much differences have been observed for garden design principles. Although most of the gardens have sufficient surrounding elements and sitting-resting areas, many of gardens are insufficient structural elements such as; parking lot, children's playground, sports area, plant boxes, lighting elements, garbage bins and water elements. After the collecting data and site observations, some information has been supplied to responders with some suggestions under landscape architecture discipline.
\end{abstract}

KEYWORDS: Apartment complex, housing development, Isparta, landscape architecture, garden.

ÖZ:

Çalışmada; Isparta kent merkezinde yer alan site ve toplu konutlar, açık ve yeşil alanlar açısından irdelenmiştir. Bahçelerde yer alan yapısal uygulamalar ile bitkisel materyaller tespit edilerek peyzaj mimarlığı bakımından

\footnotetext{
${ }^{1}$ Süleyman Demirel Üniversitesi, Mimarlık Fakültesi, Isparta-Türkiye, candansahin@sdu.edu.tr

${ }^{2}$ Lefke Avrupa Üniversitesi, Tarım Bilimleri ve Teknolojileri Fakültesi, Lefke, KKTC, maskin@eul.edu.tr

Bu çalışma, Süleyman Demirel Üniversitesi Rektörlüğü, Bilimsel Araştırma Projeleri, 1370-D-06 No'lu "Isparta Kent Merkezi Konut

Bahçelerindeki Bitkisel Materyalin İncelenmesi Üzerine Bir Araştırma" başlıklı proje kapsamında gerçekleştirilmiştir.
} 
incelenmiştir. Bu bağlamda araştırmada, Isparta kent merkezindeki toplu konutlarda bahçe ile ilgilenen kişilere anket uygulanmıştır. Isparta kent merkezindeki 23 mahallede rastgele örnekleme yöntemi ile belirlenen toplu konut bahçeleri için yüz yüze anket uygulaması yardımıyla, kullanım amaç ve şekillerinin ortaya konulması amaçlanmıştır. Toplam 23 adet anket uygulanmış ve bahçe ile ilgilenen yetkili kişilerin verdiği cevaplar değerlendirilmiştir. Bu amaçla, toplu konut/site bahçelerinde yer alan bitkisel ve yapısal materyaller ve uygulamaların yoğunluğu ve kullanım amacı açısından değerlendirilmesi yapılmıştır. Çalışmaya göre toplu konut oluşumu Isparta kent merkezi için bazı mahalleler dişında henüz yeni olduğundan, bahçe düzenlenmeleri üzerine çok fazla bir benzerlik veya farklılıktan bahsetmek söz konusu değildir. Ayrıca çalışmada bahçelerin çevreleme elemanı ve oturma-dinlenme alanı açısından yeterli olmasına rağmen otopark, çocuk oyun alanı, spor alanı, bitki kasaları, aydınlatma elemanları, çöp kutuları ve su elemanları açısından yetersiz olduğu tespit edilmiştir. Çalışmanın son aşamasında, anketlerden elde edilen veriler ve yapılan arazi gözlemleri ışığında, toplu konut ve site bahçelerinin peyzaj tasarımına yönelik önerilerde bulunulmuştur.

ANAHTAR KELIMELER: Site, toplu konut, Isparta, peyzaj mimarlığı, bahçe.

\section{GİRIŞ}

İnsanların iş dışındaki günlük yaşamlarının önemli bir bölümünün geçtiği konut alanları, sadece barınma ihtiyacını karşılayan bina dokularına veya fiziksel mekânlara indirgenmemelidir. Konut alanları hem belli fiziksel hem de sosyal ilişkilerin yaşandığı, kendilerine özgü sosyo-kültürel dokulara sahip yerleşim yerleridir. Konut dokusunun fiziksel niteliği ve sosyal karakteristikleri açısından bakıldığında, fiziksel ve sosyal dokunun bir farklılaşma içinde olduğu, bu farklılaşmanın rastlantısal bir şekilde dağılım göstermediği, belirli bazı özelliklere göre yı̆̆ılmaların, kümelenmelerin gerçekleştiği, her bir alanın kendi içinde fiziksel ve sosyal olarak benzeşim göstererek diğerlerinden ayrıldı̆̆ı ifade edilmektedir (Demir, 1998).

Konut çevresi; aynı özelliklere sahip, yani birbirine benzer insanların kümelendiği ve diğerlerinden ayrıştığ1, coğrafi ve toplumsal çevre anlamına gelmektedir (Demir, 1998). Konutlarla ilgili olarak; çevrenin tanınır olması, konut ve dış mekan arasındaki ilişki, aktif kullanılan açık alan, özel çevre, aktif şehirsel çevre, konut çevresinin düzenli olması, donatıların eksiksiz olması, sakin doğal çevre, manzara ve kirli havadan arındırılmış çevre, konutun değerini artıran koşullardır. Konut değerini azaltan koşullar ise; konut-yeşil alan kopukluğu, bahçe ve konut bakımsızlığı, sevimsiz çevre, merdiven çıkmak, zeminle duygusal ilişki kurulamaması, anonim komşuluk, ses geçirgenliği, gürültü ve hava kirliliği, hareket olanağı vermeyen, engelli bireylerin ve iklimsel konforun dikkate alınmadığı çevre şeklinde sıralanabilmektedir (Giritlioğlu, 1991; Yücedağ vd., 2017).

Hizla artan nüfus ve kırsal kesimlerden şehir merkezlerine olan göçün etkisi sonucu kentin geleneksel konut dokusunun yetersiz kalmasıyla, kentlerde genel olarak gecekondu, halk konutları, şehir içi bitişik-düzen apartman, şehir içi site ve uydu kent siteleri biçiminde tanımlanan konut alanları ortaya çıkmıştır. Özellikle son yıllarda şehir merkezlerinde hızla artan nüfus ve kırsal bölgelerden kent merkezlerine olan talep, beraberinde bazı problemleri getirmiştir. Dar alanlarda daha yüksek nüfus yoğunluğunun barınabilmesi için sorunlar, son yıllarda artan oranda çok katlı binalarla giderilmeye çalışılmaktadır. Bu durum, insanlarda doğal ve ekolojik çevre bilincinin yerleşmesini sağlamış, sıkışık şehir merkezlerinden uzak, kentlerin kenarlarında çok katlı veya müstakil konut merkezlerinin oluşumuna katkı sağlamıştır.

Toplu konut/site alanları, şehir merkezindeki sıkışıklıktan kaçan insanların, kentin yakın alanlarına yerleşmesi ile oluşmuştur. Batı Avrupa ve Kuzey Amerika'da özellikle İkinci Dünya Savaşı sonrası hızlanan kent kenarlarına göç ve yeni toplu konut alanlarının oluşumu, daha sağlıklı çevre ve yaşam alanı isteği fikrini geliştirmiştir. 19. yüzyılda gerçekleştirilen endüstri devrimi, kentlerin düzenini etkilemiş, kırsal alanlardan kentlere göçler başlamıştır. Bunun sonucunda konut gereksiniminin artmasına rağmen, mevcut konut üretimi, ihtiyaca cevap verebilecek miktarda artamamıştır. Konut maliyetlerindeki hızlı artışın da etkisiyle, yasal olmayan yapılaşma alanları (gecekondular) ortaya çıkmaya başlamıştır. Hem bu oluşuma engel olmak hem de konut açığını hızla kapatmak için, çok sayıda konut birimini içeren, yaşayan nüfus için gerekli teknik ve sosyal donatı alanları ile birlikte, planlanmış bir çevre oluşturan yerleşimler olan toplu konutlar ortaya çıkmıştır (Özyavuz ve Dönmez, 2016).

Konutlar arası ilişkilerin kurulduğu, insanların ihtiyaçlarını karşılayabilecekleri, iletişim kurabilecekleri, sosyal tesis ve yeşil alanlara sahip, altyapı problemlerinin çözüldüğü konut toplulukları olan toplu konutlar (Orhon, 1987; Atala, 2002; Dönmez vd., 2015); günümüzde tüm dünyada üzerinde en çok tartışılan konulardandır. Çünkü, niceliksel açığı kapatmak amacıyla üretilen toplu konut yerleşmeleri, büyük ölçekli projeler olduğu için, kentlerde yeni konut 
bölgeleri oluşturmakta, kentin kimliğine yeni bir imaj getirmektedir (Yüksel vd., 1996; Atakan Öznam, 2013). İnsanların konutlarında mutlu, rahat ve güvenli bir şekilde yaşayabilmeleri için konutların olduğu kadar çevrelerinin de düzenlenmesi gerekmektedir. Günümüzde insanların hem doğayla olan ilişkilerini artırarak, yeşile olan özlemlerini gidermek hem de konuta estetik değer kazandırmak açısından konut bahçeleri önem kazanmıştır.

Kentsel yaşamın getirdiği stres sonucunda kişilerin rekreasyon ihtiyaçları artmakta, bunun sonucunda kentlerde yaşayanların rahatlayabilecekleri, ruhsal ve bedensel açıdan yenilenebilecekleri, canlılık kazanabilecekleri mekanlara ihtiyaç duyulmaktadır. Bu mekânların en önemlileri, park ve bahçelerdir. Bu bağlamda incelendiğinde, konutların çevresindeki açık ve yeşil alanların, çevre kalitesi yanında insanların serbest zamanlarını değerlendirdiği bir mekân olması açısından da önemli olduğu ortaya çıkmaktadır.

Konut sakinlerinin serbest zamanlarını değerlendirmeleri açısından toplu konut/site bahçelerinin peyzaj tasarımları oldukça önemlidir. Bu nedenle, bahçelerde hem bitkisel hem de yapısal materyallerin yeterli ve uygun kullanılması, kişilerin memnuniyetini de arttırmaktadır. Bu kapsamda yapılan çalışmada; Isparta kent merkezinde farklı mahallelerde yer alan toplu konutların/sitelerin mevcut açık ve yeşil alanları incelenmiş, peyzaj tasarım kriterlerine göre değerlendirilmeleri yapılmıştır. Çalışma kapsamında, her bir toplu konutta/sitede bahçe ile ilgilenen kişilere hazırlanan formlarla anket uygulanmış, çalışma sonunda ayrı ayrı değerlendirilmiştir.

\section{MATERYAL ve YÖNTEM}

Çalışmanın materyalini; Isparta kent merkezinde, farklı mahallelerde bulunan toplu konut/site bahçeleri ile bu bahçelerin kullanıcıları oluşturmaktadır. Isparta, Akdeniz Bölgesi'nin kuzeyinde Göller Bölgesi'nde irili ufaklı onlarca gölün arasında bulunmaktadır. İl, $30^{\circ} 20^{\prime}$ ve $31^{\circ} 33^{\prime}$ doğu boylamları ile $37^{\circ} 18^{\prime}$ ve $38^{\circ} 30^{\prime}$ kuzey enlemleri

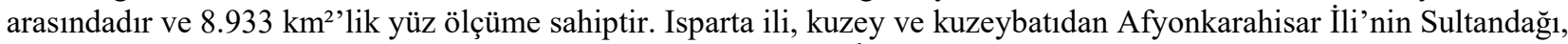
Çay, Şuhut, Dinar ve Dazkırı, batıdan ve güneybatıdan Burdur İli'nin Merkez, Ağlasun ve Bucak, güneyden Antalya İli’nin Serik ve Manavgat, doğu ve güneydoğudan ise Konya İli’nin Akşehir, Doğanhisar ve Beyşehir ilçeleri ile çevrilmiştir (Anonim, 1). Şekil 1'de Isparta ili ve çevresinin yerleşimi verilmiştir.



Şekil 1. Isparta İli ve çevresi (Anonim, 2) 
Isparta; kışları 1lık ve yağışlı, yazları sıcak ve kurak bir iklime sahiptir. Isparta kent merkezinin yıllık sıcaklık ortalamasının $12,4{ }^{\circ} \mathrm{C}$ olduğu belirlenmiştir. Yılın en soğuk ayları genellikle Ocak ve Şubat ayları, en sıcak aylar ise Temmuz ve Ağustos aylarıdır. İlin ortalama yıllık yağıș toplamı $612,6 \mathrm{~kg} / \mathrm{m}^{2}$ 'dir (Anonim, 3).

Çalışmanın yöntemi; literatür taraması, veri toplama, inceleme ve yerinde gözlem, analiz ve değerlendirme aşamalarından oluşmaktadır. Bahçeler; yerinde, ayrıntılı olarak incelenmiş, alanda bulunan bitkiler not edilmiş, kullanım amaçları, yoğunlukları ile bitkisel tasarım açısından değerlendirilmeler yapılmıştır. Standart anket formları ile Isparta kent merkezindeki toplu konutlarda, yüzyüze metodu ile anket uygulanmış ve elde edilen veriler değerlendirilmiştir. Araştırmada hedeflenen sonuca ulaşabilmek için, bahçe ile en fazla ilgilenen veya bahçeye en fazla eğilimi olan kişi (çoğunlukla yönetici, kapıcı veya bahçıvan vb.) ile yüz yüze görüşülerek anket uygulaması yapılmıştır. Ayrıca, ziyaret edilen toplu konut/site bahçeleri ile kullanılan bitkisel materyalin durumunu yansıtacak fotoğraflar çekilmiştir.

Toplu konutların/sitelerin örnek popülasyonunun gerçek popülasyonu temsil ettiği düşünülen mahallerde rastgele basit örnekleme metodu kullanılarak konutlar belirlenmiştir. Isparta eski yerleşim merkezi olan ve günümüzde merkezi oluşturan mahallelerin tamamında, ayrıca bazı kenar mahallelerde çok katlı toplu konut/site alanlarına rastlanılmamıştır. $\mathrm{Bu}$ tip konutlara sadece kentin genişleme yönündeki yeni kurulan bazı mahallelerinde rastlanılmıştır. Konut yapısı ve aynı alanda çok fazla konutun bulunması, bu alanlar için örnek büyüklüğünün seçiminde sorunlar oluşturacağı düşünülerek 23 mahallede her mahalle için 1 toplu konut bahçesi seçilerek anket uygulanmış ve toplam anket sayısı 23 olarak tespit edilmiştir. Çalışma amacına uygun toplu konut bulunmaması, inşaatların henüz yeni tamamlanmış olması ve peyzaj tasarım çalışmalarının yapılmamış olması gibi nedenlerle diğer 20 mahalle anket çalışmasına dâhil edilmemiştir. Tablo 1'de anket uygulanan toplu konut bahçelerinin bulunduğu mahalleler ve anket sayıları verilmiştir.

Tablo 1. Isparta kent merkezindeki inceleme yapılan toplu konut bahçeleri ve bulundukları mahalleler

\begin{tabular}{|c|c|c|c|c|c|}
\hline Sıra No & $\begin{array}{c}\text { Anket Uygulanan Mahalle } \\
\text { İsmi }\end{array}$ & $\begin{array}{c}\text { Anket sayısı } \\
\text { (adet) }\end{array}$ & Sıra No & Anket Uygulanan Mahalle İsmi & $\begin{array}{c}\text { Anket sayısı } \\
\text { (adet) }\end{array}$ \\
\hline 1 & Anadolu Mahallesi & 1 & 13 & Işıkkent Mahallesi & 1 \\
2 & Ayazman Mahallesi & 1 & 14 & Karaağaç Mahallesi & 1 \\
3 & Batıkent Mahallesi & 1 & 15 & Keçeci Mahallesi & 1 \\
4 & Binbirevler Mahallesi & 1 & 16 & Kurtuluş Mahallesi & 1 \\
5 & Çünür Mahallesi & 1 & 17 & Modernevler Mahallesi & 1 \\
6 & Davraz Mahallesi & 1 & 18 & Muzaffer Türkeş Mahallesi & 1 \\
7 & Doğancı Mahallesi & 1 & 19 & Pirimehmet Mahallesi & 1 \\
8 & Fatih Mahallesi & 1 & 20 & Sermet Mahallesi & 1 \\
9 & Gülistan Mahallesi & 1 & 21 & Sidre Mahallesi & 1 \\
10 & Halıkent Mahallesi & 1 & 22 & Turan Mahallesi & 1 \\
11 & Hizırbey Mahallesi & 1 & 23 & Vatan Mahallesi & 1 \\
12 & İskender Mahallesi & 1 & & Genel Toplam & 23 \\
\hline
\end{tabular}

Anket uygulamaları Mayıs-Eylül ayları arasında, havanın sıcak ve güneşli olduğu zamanlarda yapılmıştır. Anket uygulaması temsil açısından daha kapsamlı olması amacıyla, hafta içi ve hafta sonu, farklı saatlerde yapılmış̧ır. Her bir anketin uygulanması yaklaşık 15 dakika sürmüştür. Anket sonrası bahçe detaylı bir şekilde irdelenmiş, alan büyüklükleri hesaplanmış, bitkisel materyallerin tür ve sayıları not edilmiştir.

Isparta kent merkezindeki toplu konutlardaki/sitelerdeki bahçelerin kullanım şekillerinin ve bahçelerdeki bitkisel ve yapısal materyallerin belirlenmesi aşamasında uygulanan anketler SPSS 13.0 (Statistical Program for the Social Science) istatistik programının yardımıyla değerlendirilerek, tablolar haline getirilmiştir. Sonuçta da elde edilen verilere iliş̧in öneriler geliştirilmiştir.

\section{BULGULAR}




\subsection{Bahçelere İlişskin Veriler}

Isparta kent merkezinde çok katlı blok apartmanlardan oluşan toplu yerleşim birimlerinde, 23 mahallede toplam 23 adet anket çalışması yapılmıştır.

Toplu konutların/sitelerin bahçeleri ile genellikle (\%39) çalışan ve çoğunlukla kapıcı olarak adlandırılan, site görevlilerin ilgilendiği anlaşılmıştır. Bu kişiler sitedeki asıl görevleri yanında bahçe bakımı işlerini de gerçekleştirmektedirler. Bahçelerle konutlarda ikamet edenlerin (\%22), kalorifer yakmakla görevli kişilerin (\%22) ve yöneticilerin $(\% 17)$ de ilgilendiği görülmüştür. Bahçe ile ilgilenilmeyen herhangi bir toplu konuta/siteye rastlanılmamıştır. Bahçeler ile ilgilenen kişilerin dağılımı Tablo 2'de verilmiştir.

Toplu konut/site bahçelerinin büyük çoğunluğunun (\%74) $300 \mathrm{~m}^{2}$ 'den büyük olduğu saptanmıştır (Tablo 2). Bu durum, peyzaj uygulamalarının gerçekleştirilebilmesi açısından oldukça elverişli durum arz etmektedir.

Tablo 2. Toplu konutların bahçeleri ile ilgilenenler kişiler ve bahçe büyüklükleri

\begin{tabular}{|llcc|}
\hline Değişkenler & $\begin{array}{c}\text { Seçilme } \\
\text { Sayısı }\end{array}$ & $\begin{array}{c}\text { Oranı } \\
(\%)\end{array}$ \\
\hline Bahçe İle İlgilenen Kişi & Site görevlisi (Kapıc1) & 9 & 39 \\
& Kalorifer yakan kişi & 5 & 22 \\
& Toplu konut sakinleri & 5 & 22 \\
& Yönetici & 4 & 17 \\
\hline Bahçe Büyüklü̆̆̈u & $101-150 \mathrm{~m}^{2}$ & 2 & 9 \\
& $151-200 \mathrm{~m}^{2}$ & 3 & 13 \\
& $201-300 \mathrm{~m}^{2}$ & 1 & 4 \\
& $>300 \mathrm{~m}^{2}$ & 17 & 74 \\
\hline
\end{tabular}

Toplu konut bahçelerinde çevre düzenlenmesi ile ilgili elde edilen veriler Tablo 3 'te verilmiştir. Buna göre; toplu konutların büyük çoğunluğunun (\%74) peyzaj tasarım projesi bulunmadığı, projesi bulunan toplu konutların (\%26) ise Hızırbey, Sermet, Kurtuluş, Keçeci, Işıkkent ve Çünür mahallelerinde olduğu tespit edilmiştir. Toplu konutların peyzaj uygulamasını yapan kişilerin, bahçeyle ilgilenen kişilerle benzerlik gösterdiği anlaşılmıştır. Çevre düzenlemesi ile daha çok site görevlilerinin (\%26) ve konut sakinlerinin (\%26) ilgilendikleri görülmektedir.

Toplu konut/site bahçelerinin uygulamalarını peyzaj mimarlarına veya peyzaj uygulama işleri ile ilgilenen kişi veya şirketlere yaptıranların oranı ise $\% 17$ olarak tespit edilmiştir. Toplu konut/site bahçelerinin büyük çoğunluğunda (\%72) düzenli olarak bakım yapıldığı tespit edilmiştir. Toplu konut/site bahçelerinde düzenli bakım yapılmamasının nedenleri arasında sırasıyla; maddi nedenler, zaman yetersizliği, bahçe alanının dar olması gelmektedir. Toplu konutların büyük çoğunluğunda (\%78) bahçe için harcama yapıldığı gözlemlenmiştir (Tablo 3).

Tablo 3. Toplu konutların genel bahçe düzenlenme durumları

\begin{tabular}{|llcc|}
\hline Değişkenler & & $\begin{array}{c}\text { Seçilme } \\
\text { Sayısı }\end{array}$ & $\begin{array}{c}\text { Oranı } \\
(\%)\end{array}$ \\
\hline Peyzaj Tasarım Projesi Çizdirilme Durumu & Evet & 6 & 26 \\
& Hayır & 17 & 74 \\
& Bilinmiyor / Bilgi alınamadı & 0 & 0 \\
\hline Peyzaj Uygulaması Yapan Kişi & Site görevlisi (Kapıcı) & 6 & 26 \\
& Kalorifer yakan kişi & 2 & 9 \\
& Yönetici & 2 & 9 \\
& Toplu konut sakinleri & 6 & 26 \\
& Bilinmiyor / Bilgi alınamadı & 3 & 13 \\
& Peyzaj Mimarı / Peyzaj Şirketi & 4 & 17 \\
\hline Bahçede Düzenli Bakım Yapılma Durumu & Evet & 18 & 78 \\
& Hayır & 5 & 22 \\
& Bilinmiyor / Bilgi alınamadı & 0 & 0 \\
\hline Bahçede Harcama Yapılma Durumu & Evet & 18 & 78 \\
\hline
\end{tabular}




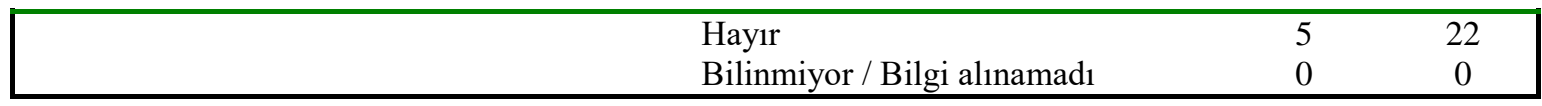

\subsection{Bahçelerdeki Yapısal Uygulama ve Materyaller}

Toplu konut/site bahçelerini kullananlar ile mevsimlere göre ve gün içinde kullanım şekilleri ve kullanım amaçları Tablo 4'te yer almaktadır. Buna göre; toplu konut bahçelerini en fazla çocukların, daha sonra kadınların ve gençlerin kullandıkları tespit edilmiştir. Yaşlıların ve erkeklerin ise bahçeyi çok az oranda kullandıkları anlaşılmaktadır. Toplu konutların bahçelerinin en fazla yaz aylarında, daha sonra sırası ile ilkbahar ve sonbahar aylarında kullanıldığı, kış mevsiminde ise kullanılmadığı anlaşılmıştır. Bahçenin gün içinde en fazla öğleden sonra kullanıldığı, bunu sabah, akşam ve öğlen saatlerinin izlediği tespit edilmiştir. Ayrıca; toplu konut/site bahçelerinin daha çok; oyun oynamak, oturmak, serbest zaman geçirmek ve yemek yemek için kullanıldığı görülmektedir. Ayrıca toplu konutlarda/sitelerde oturan kişilerin bahçelerini sadece otopark olarak kullanımları da söz konusudur. Bu durum, bazen bitki yetiştirmek için yetersiz olan bahçe alanının daha da azalmasına sebep olmaktadır. Bahçenin kullanım amacı ve zamanı genel olarak değerlendirildiğinde; en fazla yaz mevsiminde ve öğleden sonra kadınlar tarafindan oturmak ve çocuklar tarafindan da oyun oynamak için kullandıkları tespit edilmiştir. Bahçelerin \%78'inde oturma-dinlenme için ayrılmış alanlar bulunmaktadır (Tablo 4).

Tablo 4. Toplu konut bahçelerini en fazla kullananlar, kullanım zamanları ve kullanım amaçları

\begin{tabular}{|c|c|c|}
\hline Değişkenler & & Seçilme Sayısı \\
\hline Bahçeyi En Fazla Kullananlar & $\begin{array}{l}\text { Yaşlılar } \\
\text { Çocuklar } \\
\text { Gençler } \\
\text { Kadınlar } \\
\text { Erkekler } \\
\text { Kullanılmıyor }\end{array}$ & $\begin{array}{c}1 \\
15 \\
3 \\
13 \\
1 \\
5\end{array}$ \\
\hline Bahçenin En Fazla Kullanıldığı Mevsim & $\begin{array}{l}\text { Yaz } \\
\text { İlkbahar } \\
\text { Kış } \\
\text { Sonbahar } \\
\text { Kullanılmıyor } \\
\text { Bilgi alınamadı }\end{array}$ & $\begin{array}{c}15 \\
8 \\
0 \\
2 \\
5 \\
0\end{array}$ \\
\hline Bahçenin Gün İçinde En Fazla Kullanıldığı Zaman & $\begin{array}{l}\text { Sabah } \\
\text { Öğle } \\
\text { Öğleden sonra } \\
\text { Akşam } \\
\text { Kullanılmıyor } \\
\text { Bilgi alınamadı }\end{array}$ & $\begin{array}{c}4 \\
1 \\
15 \\
5 \\
5 \\
0\end{array}$ \\
\hline Bahçelerin En Fazla Kullanım Amaçları & $\begin{array}{l}\text { Oturmak } \\
\text { Oyun oynamak } \\
\text { Boş zaman geçirmek } \\
\text { Yemek yemek } \\
\text { Otopark } \\
\text { Kullanılmıyor }\end{array}$ & $\begin{array}{c}11 \\
14 \\
5 \\
1 \\
2 \\
5\end{array}$ \\
\hline
\end{tabular}

Şekil 2'de bahçelerin kullanım amaçlarına ilişkin örnekler yer almaktadır. 

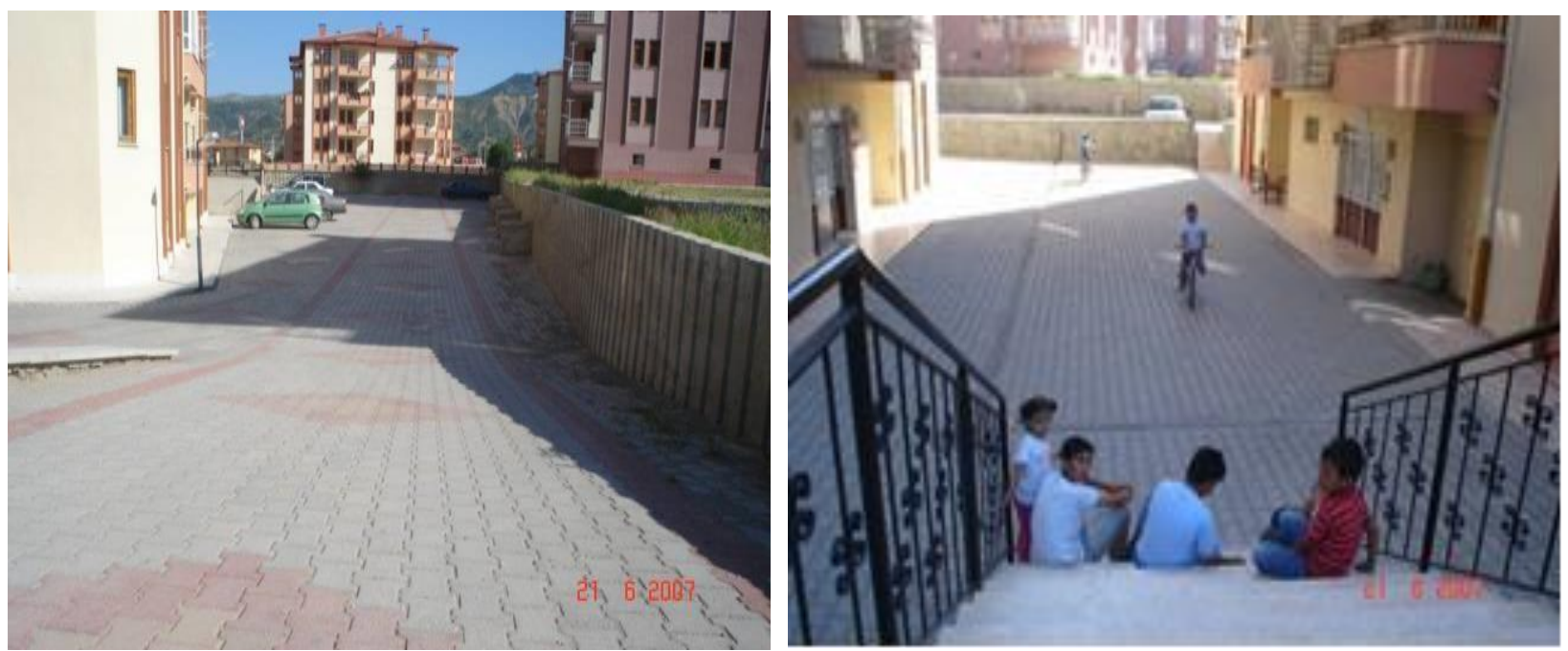

Şekil 2. Toplu konut bahçesinin oyun ve otopark olarak kullanımları

Çalışmada incelenen site ve toplu konutlara ilişkin yapısal bulgular Şekil 3’te verilmiştir. Buna göre, sitelerin \%35'inde otopark mevcuttur. Otoparkı bulunmayan sitelerde ikamet edenler, araçlarını site sınırları dışına, yol kenarına park etmektedirler.

Sitelerin/toplu konutların sadece \%13'ünde çocuk oyun alanı bulunurken \%9'unda spor alanı yer almaktadır (Şekil 3). Çocuklar için ayrılmış oyun alanları yetersiz olduğu için çocuklar bahçelerin her yerini oyun oynamak ve bisiklet sürmek için kullanmaktadırlar (Şekil 2).

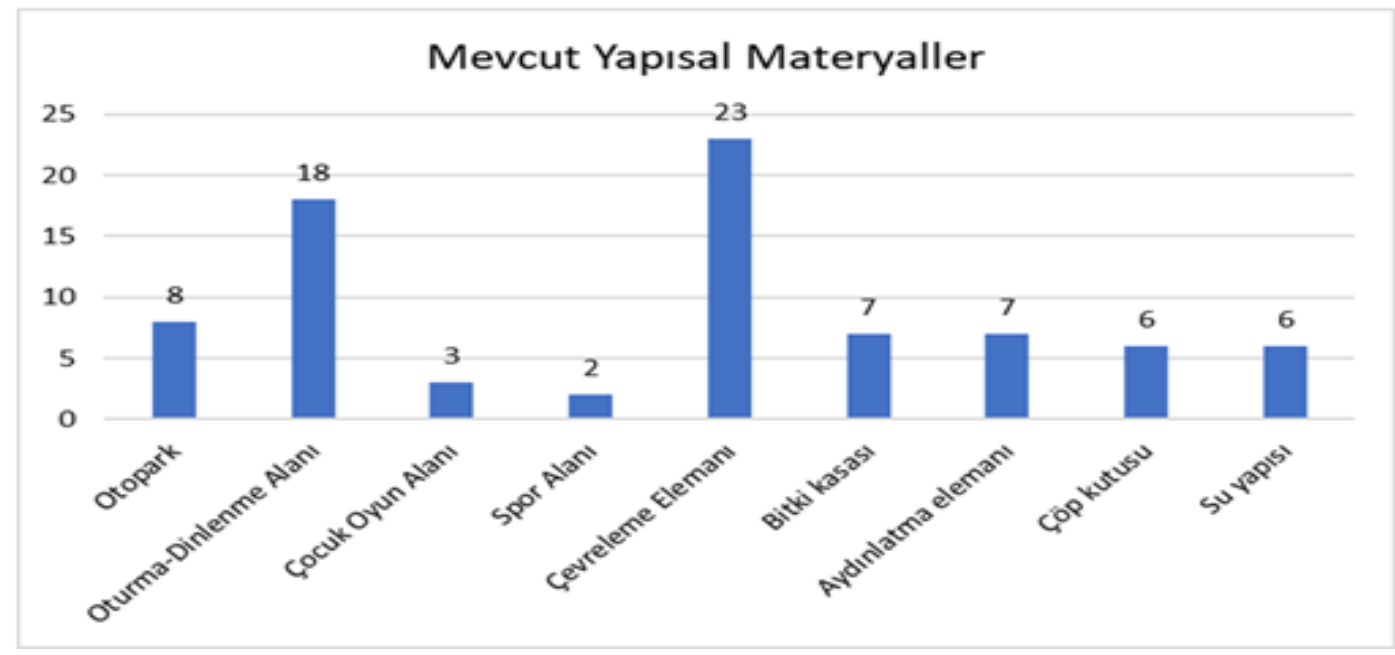

Şekil 3. Toplu konut / site bahçelerinde yer alan yapısal uygulamalar

Toplu konut/site bahçelerine yabancı insan veya hayvanların girmesinin engellenmek istendiği durumlarda, $180 \mathrm{~cm}$ ile $250 \mathrm{~cm}$ arasında değişen yükseklikte çevreleme elemanlarının yapılması gerekmektedir. Sadece sınırların belirlenmesi istendiğinde, daha alçak çevreleme elemanları kullanılabilir. İnceleme yapılan bahçelerin tamamında çevreleme söz konusudur (Şekil 3). Ancak bahçelerdeki çevreleme elemanlarının öncelikle mahremiyeti sağlamak amacı ile yapıldığı belirlenmiştir. Bu amaçla kullanılmış olan çevreleme elemanlarıyla birlikte ve aynı zamanda kot farkı olan bahçelerde yer alan merdivenlerin kenarlarında, yapısal malzemelerin, özellikle taş ve betonun yarattığı soğuk görüntüyü ve mimari etkiyi giderici (Hedera helix L. (Duvar sarmaşığı), Parthenocissus quinquefolia L. (Amerikan sarmaşığı), Wisteria sinensis (Sims.) DC. (Mor salkım), Campsis radicans (L.) Seem. (Acem borusu), Lonicera caprifolium L. (Sarılıcı hanımeli) vb) bitkilere yer verilmiştir. Böylece mekâna canlılık kazandırılmıştır (Şekil 4). Bunların yanı sıra yüksek olarak inşa edilmiş ve bitkisel materyallerle desteklenmemiş çevreleme elemanlarına da rastlamak mümkündür 
(Şekil 5). Toplu konutlarda/sitelerde, bahçe içinde mekânları ayırmak için yapısal elemanların yerine bitkisel materyaller de kullanılmıştır. Bu amaçla çit bitkisi olarak kullanılan türler tercih edilmiştir. Ancak bu durum bitkilerin sağlıklı bir şekilde gelişimine engel olabilmektedir.

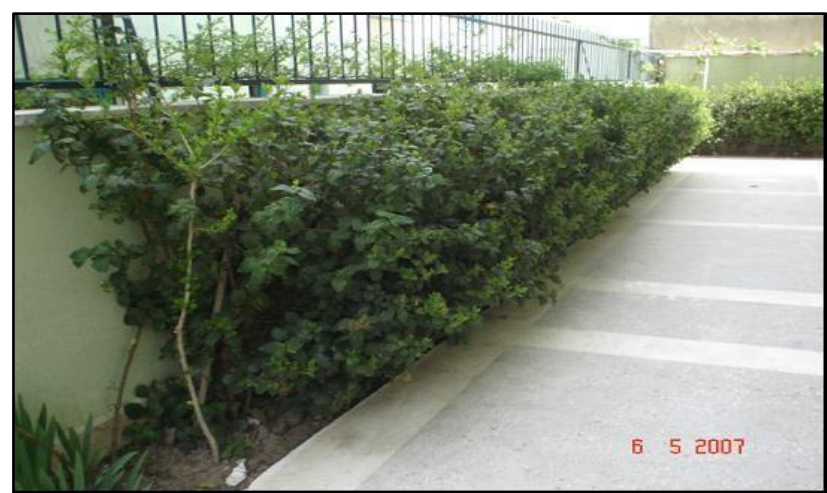

Şekil 4. Bitkisel- yapısal elemanların birlikte kullanımı

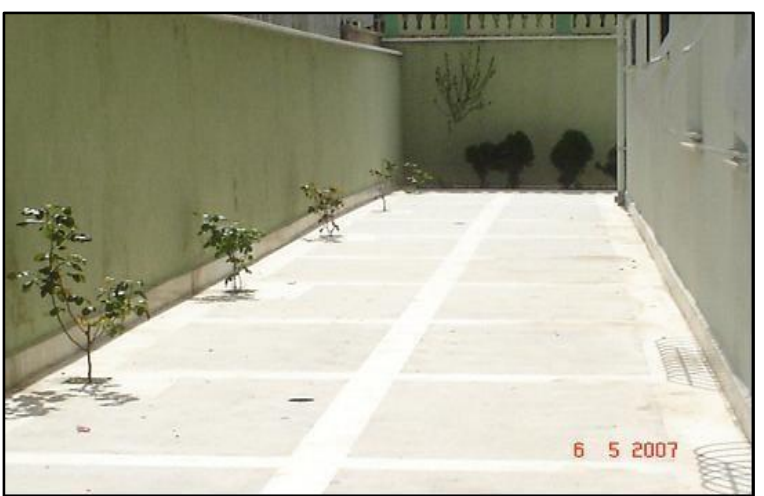

Şekil 5. Yüksek çevreleme elemanı

Bahçelerde yeşil alanlarda bitkilerin kullanımı söz konusudur. Ancak bununla birlikte, bahçelerin \%30'unda bitki kasalarında ve saksılarda bitkilere de yer verilmiştir. Bahçelerde, gün ışığının yeterli olmadığı, akşam ve gece kullanımında emniyet ve güvenliği sağlamak için aydınlatma yapılması gerekmektedir. Bahçelerin kullanımında bu kadar önemli olan aydınlatma elemanları, inceleme yapılan bahçelerin sadece \%30'unda yer almaktadır (Şekil 6).

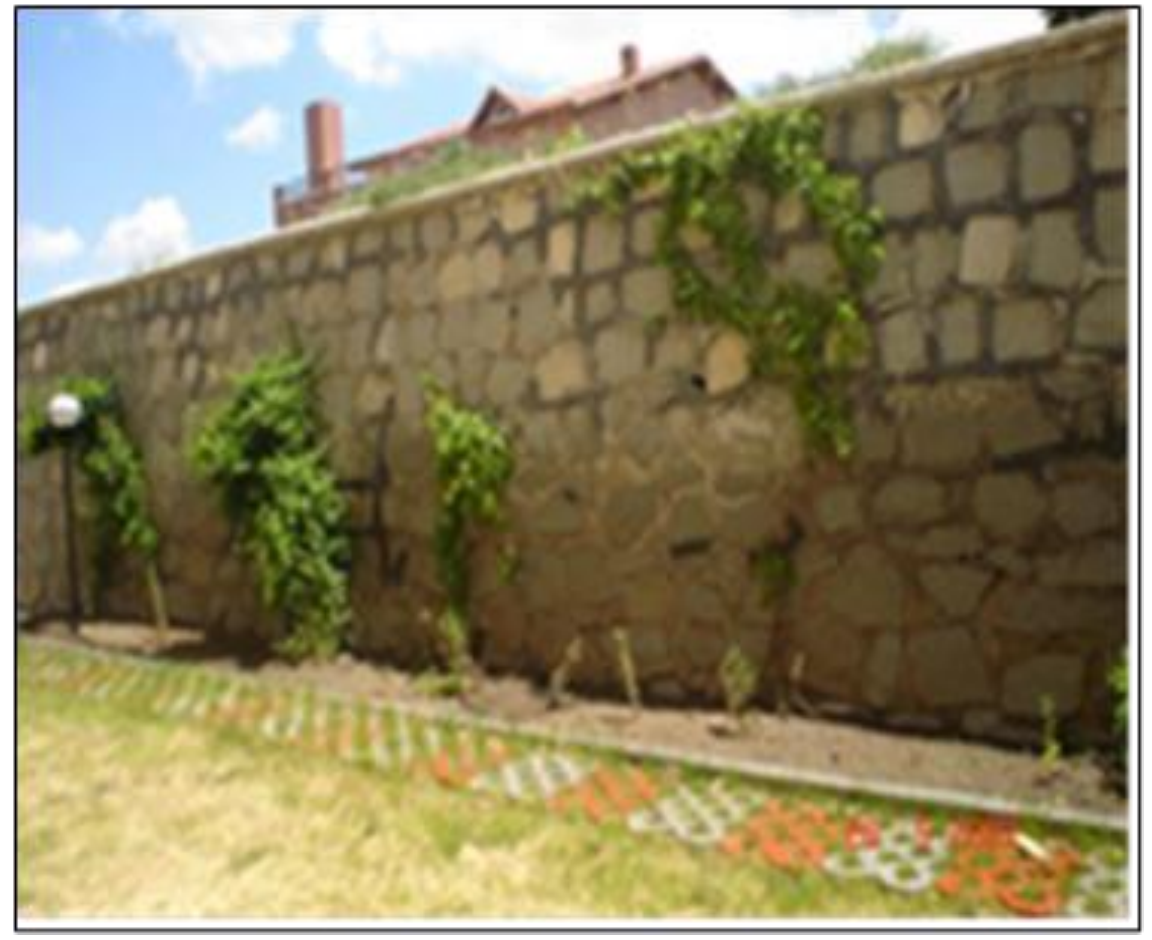

Şekil 6. Duvar önü aydınlatma elemanı

Bahçesinde çöp kutusu bulunan toplu konutların/sitelerin oranı \%26'dır. Oldukça düşük bir orandadır. Bahçelerde yer alan su elemanlarının oranı da yine \%26 olarak belirlenmiştir.

\subsection{Bahçelerdeki Bitkisel Uygulama ve Materyaller}

Çalışma sırasında yerinde yapılan incelemeler sonucu, toplu konut/site bahçelerinde gözlemlenen odunsu ve otsu bitkiler ve bulunma sayıları Tablo 5'te verilmiştir. 
Tablo 5. Isparta kent merkezindeki toplu konut bahçelerinde bulunan bitkisel materyaller ve rastlanma sayıları

\begin{tabular}{|c|c|c|c|}
\hline \multicolumn{4}{|c|}{ GENIŞ YAPRAKLI AĞAÇLAR } \\
\hline AMILYA ADI & LATINCE ADI & TÜRKÇE ADI & ADET \\
\hline Tiliaceae & Tilia argentea Desf. & Gümüşi ihlamur & 7 \\
\hline Salicaceae & Salix babylonica $\mathrm{L}$. & Salkım söğüt & 6 \\
\hline Salicaceae & Populus alba $\mathrm{L}$. & Akkavak & 3 \\
\hline Platanaceae & Platanus orientalis L. & Doğu çınarı & 3 \\
\hline Simoribaceae & Ailanthus altissima $\mathrm{L}$. & Cennet ağacı & 2 \\
\hline Leguminosae & Robinia pseudacacia $\mathrm{L}$. & Yalanc1 akasya & 2 \\
\hline Aceraceae & Acer negundo L. & Dişbudak yapraklı akçaağaç & 2 \\
\hline Lauraceae & Laurus nobilis L. & Akdeniz defnesi & 1 \\
\hline Oleaceae & Fraxinus excelsior $\mathrm{L}$. & Adi dişbudak & 1 \\
\hline Bignoniaceae & Catalpa bignonioides Walt & Büyük yapraklı katalpa & 1 \\
\hline \multicolumn{4}{|c|}{ İĞNE YAPRAKLI AĞAÇLAR } \\
\hline FAMILYA ADI & LATÍNCE ADI & TÜRKÇE ADI & ADET \\
\hline Pinaceae & Cedrus libani A. Rich. & Toros sediri & 12 \\
\hline Cupressaceae & Cupressus sempervirens $\mathrm{L}$. & Mezarlık servisi & 12 \\
\hline Cupressaceae & Juniperus sabina L. & Sabin ardıc1 & 12 \\
\hline Cupressaceae & Biota orientalis (L.) Endl. & Doğu mazıs1 & 12 \\
\hline Pinaceae & Pinus nigra $\mathrm{L}$. & Kara çam & 10 \\
\hline Pinaceae & Picea abies $\mathrm{L}$. & Avrupa ladini & 5 \\
\hline Cupressaceae & Cupressus macrocarpa 'Gold Crest' & Limoni servi & 4 \\
\hline Taxaceae & Taxus baccata $\mathrm{L}$. & Adi porsuk & 2 \\
\hline \multicolumn{4}{|c|}{ AĞAÇCIKLAR VE ÇALILAR } \\
\hline FAMILYA ADI & LATİNCE ADI & TÜRKÇE ADI & ADET \\
\hline Rosaceae & Rosa spp. & Gül & 22 \\
\hline Caprifoliaceae & Lonicera nitida $\mathrm{L}$. & Hanımeli, Parlak hanımeli & 8 \\
\hline Oleaceae & Syringa vulgaris $\mathrm{L}$. & Leylak, Adi leylak & 8 \\
\hline Celastraceae & Euоnутия japonica $\mathrm{L}$. & Taflan & 8 \\
\hline Celastraceae & Euonymus japonica "aureus" & Sarı alacalı taflan & 6 \\
\hline Rosaceae & Cotoneaster horizontalis Decne. & Yayılıcı dağ muşmulası & 6 \\
\hline Apocynaceae & Nerium oleander $\mathrm{L}$. & Zakkum & 5 \\
\hline Rosaceae & Pyracantha coccinea Roem. & Ateş dikeni & 4 \\
\hline Oleaceae & Ligustrum vulgare $\mathrm{L}$. & Adi kurtbağrı & 3 \\
\hline Buxaceae & Buxus sempervirens L. & Şimşir, Adi şimşir & 3 \\
\hline Caprifoliaceae & Viburnum oplulus L. & Kartopu, Adi kartopu & 2 \\
\hline Hydrangeaceae & Hydrangea arborescens $\mathrm{L}$. & Ortanca & 2 \\
\hline Malvaceae & Hibiscus syriacus $\mathrm{L}$. & Ağaç hatmi & 2 \\
\hline Myrtaceae & Callistemon citrinus $\mathrm{L}$. & Firça çalıs1 & 2 \\
\hline Buddlejaceae & Buddleia davidii Franch. & Kelebek çalısı & 1 \\
\hline Oleaceae & Jasminum fruticans $\mathrm{L}$. & Sarı çiçekli yasemin & 1 \\
\hline Berberidaceae & Mahonia aquifolium Nutt. & Mahonya, sarıboya & 1 \\
\hline Oleaceae & Jasminum officinale L. & Beyaz çiçekli yasemin & 1 \\
\hline Berberidaceae & Berberis thunbergii var. atropurpurea & Kırmızı yapraklı kadın tuzluğu & 1 \\
\hline \multicolumn{4}{|c|}{ SARILICI VE TIRMANICI BİTKILLER } \\
\hline FAMÍLYA ADI & LATÍNCE ADI & TÜRKÇE ADI & ADET \\
\hline Araliaceae & Hedera helix $\mathrm{L}$. & Kaya sarmaşığı & 8 \\
\hline Vitaceae & Parthenocissus quinquefolia $\mathrm{L}$. & Amerikan sarmaşı̆̆1 & 8 \\
\hline Caprifoliaceae & Lonicera caprifolium $\mathrm{L}$. & Hanımeli, Keçikulağ 1 & 7 \\
\hline Leguminosae & Wisteria sinensis (Sims.) DC. & Mor salkım & 6 \\
\hline Rosaceae & Rosa wickuriana & Sarılıcı gül & 4 \\
\hline
\end{tabular}




\begin{tabular}{|c|c|c|c|}
\hline Bignoniaceae & Campsis radicans (L.) Seem. & Acem borusu & 1 \\
\hline \multicolumn{4}{|c|}{ TEK, İKİ VE ÇOK YILLIK ÇİÇEKLER } \\
\hline FAMILYA ADI & LATINCE ADI & TÜRKÇE ADI & ADET \\
\hline Liliaceae & Lilium canadense $\mathrm{L}$. & Zambak & 14 \\
\hline Scrophulariaceae & Antirrhinum majus L. & AslanağZ1 & 13 \\
\hline Violaceae & Viola tricolor maxima & Hercai menekşe & 8 \\
\hline Asteraceae & Tagetes erecta $\mathrm{L}$. & Kadife çiçeği & 8 \\
\hline Lamiaceae & Rosmarinus officinalis L. & Biberiye & 7 \\
\hline Compositae & Chrysanthemum coronarium $\mathrm{L}$. & Krizantem & 6 \\
\hline Asteraceae & Calendula officinalis & Portakal nergisi & 6 \\
\hline Asteraceae & Bellis perennis $\mathrm{L}$. & İstanbul papatyası & 5 \\
\hline Brassicaceae & Cheiranthus cheiri L. & Şebboy & 5 \\
\hline Malvaceae & Althaea rosea (L.) Cav. & Gülhatmi & 5 \\
\hline Solanaceae & Petunia $x$ hybrida Vilm. & Petunya & 4 \\
\hline Campanulaceae & Campanula medium $\mathrm{L}$. & Çan çiçeği & 3 \\
\hline Polemoniaceae & Phlox paniculata $\mathrm{L}$. & Alev çiçeği & 3 \\
\hline Asteraceae & Anthemis maritima L. & Papatya (beyaz) & 3 \\
\hline Lamiaceae & Salvia splendens $\mathrm{L}$. & Ateş çiçeği & 3 \\
\hline Lamiaceae & Lavandula officinalis L. & Lavanta & 3 \\
\hline Nyctaginaceae & Mirabilis jalapa $\mathrm{L}$. & Gece sefas 1 & 3 \\
\hline Primulaceae & Primula vulgaris $L$. & Çuha çiçeği & 2 \\
\hline Liliaceae & Hyacinthus orientalis $\mathrm{L}$. & Sümbül & 2 \\
\hline Caryophyllaceae & Dianthus barbatus L. & Hüsnüyusuf & 2 \\
\hline Amaranthaceae & Celosia plumosa L. & Horozibiği & 2 \\
\hline Iridaceae & Iris germanica $\mathrm{L}$. & Süsen & 2 \\
\hline Portulacaceae & Portulaca grandiflora $\mathrm{L}$. & Kedi tırnağ1 & 1 \\
\hline Apocynaceae & Vinca major $\mathrm{L}$. & Cezayir menekşesi & 1 \\
\hline Asteraceae & Anthemis tinctoria $\mathrm{L}$. & Papatya (sar1) & 1 \\
\hline Asteraceae & Helichrysum bracteatum L. & Kağıt çiçeği & 1 \\
\hline Caryophyllaceae & Dianthus caryophyllus L. & Karanfil & 1 \\
\hline Asteraceae & Gazania rigens $\mathrm{L}$. & Gazanya, & 1 \\
\hline Verbenaceae & Verbena hybrida L. & Mine çiçeği & 1 \\
\hline Asteraceae & Zinnia elegans L. & Kirli hanım çiçeği, Zinya & 1 \\
\hline Begoniaceae & Begonia semperflorens L. & Begonya, & 1 \\
\hline Cannaceae & Canna indica $\mathrm{L}$. & Kanna & 1 \\
\hline \multicolumn{4}{|l|}{ MEYVELER } \\
\hline FAMILYA ADI & LATINCE ADI & TÜRKÇE ADI & ADET \\
\hline Vitaceae & Vitis vinifera $\mathrm{L}$. & Asma & 13 \\
\hline Rosaceae & Prunus armeniaca $\mathrm{L}$. & Kay1s1 & 10 \\
\hline Rosaceae & Prunus domestica L. & Erik & 7 \\
\hline Rosaceae & Prunus avium L. & Kiraz & 7 \\
\hline Rosaceae & Cydonia vulgaris Pers. & Ayva & 5 \\
\hline Rosaceae & Fragaria vesca $\mathrm{L}$. & Çilek & 5 \\
\hline Rosaceae & Prunus persica L. & Şeftali & 5 \\
\hline Rosaceae & Amygdalus communis L. & Badem & 4 \\
\hline Juglandaceae & Juglans regia L. & Ceviz & 4 \\
\hline Moraceae & Ficus carica $\mathrm{L}$. & İncir & 4 \\
\hline Rosaceae & Ribes aureum Pursh. & Frenk üzümü & 3 \\
\hline Moraceae & Morus alba $\mathrm{L}$. & Ak dut & 3 \\
\hline Eleagnaceae & Eleagnus angustifolia $\mathrm{L}$. & İğde & 3 \\
\hline Betulaceae & Corylus avellana $\mathrm{L}$. & Findık & 3 \\
\hline
\end{tabular}




\begin{tabular}{|c|c|c|c|}
\hline Rosaceae & Eriobotrya japonica $\mathrm{L}$. & Yeni dünya, Malta eriği & 2 \\
\hline Cornaceae & Cornus mas L. & Ergen, Kızılcık & 2 \\
\hline Punicaceae & Punica granatum $\mathrm{L}$. & Nar & 2 \\
\hline Rosaceae & Pyrus communis $\mathrm{L}$. & Armut & 2 \\
\hline Rosaceae & Malus communis L. & Elma & 1 \\
\hline Rosaceae & Prunus cerasus L. & Vişne & 1 \\
\hline Oleaceae & Olea europea L. & Zeytin & 1 \\
\hline Rosaceae & Diospyros kaki L. & Trabzon hurmas1 & 1 \\
\hline \multicolumn{4}{|l|}{ SEBZELER } \\
\hline FAMILYA ADI & LATINCE ADI & TÜRKÇE ADI & ADET \\
\hline Alliaceae & Allium cepa $\mathrm{L}$. & Soğan & 9 \\
\hline Solanaceae & Lycopersicon esculentum L. & Domates & 8 \\
\hline Labiatea & Mentha piperita $\mathrm{L}$. & Nane & 8 \\
\hline Solanaceae & Capsicum annum $\mathrm{L}$. & Biber & 6 \\
\hline Leguminosae & Phaseolus vulgaris L. & Fasulye & 4 \\
\hline Compositeae & Lactuca sativa var. longifolia $\mathrm{L}$. & Marul & 2 \\
\hline Umbelliferae & Petroselinum hortense Hoffm & Maydanoz & 2 \\
\hline Compositeae & Helianthus tuberosus L. & Yerelmas1 & 2 \\
\hline Cruciferae & Lepidium sativum $\mathrm{L}$. & Tere otu & 2 \\
\hline Alliaceae & Allium sativum $\mathrm{L}$. & Sarımsak & 2 \\
\hline Portulacaceae & Portulaca oleraceae L. & Semizotu & 2 \\
\hline Papaveraceae & Papaver Somniferum L. & Haşhaş & 2 \\
\hline Alliaceae & Allium porrum L. & P1rasa & 2 \\
\hline Polygononaceae & Rumex acetosa $\mathrm{L}$. & Kuzu kulağ & 1 \\
\hline Cucurbitaceae & Cucurbita pepo L. & Kabak & 1 \\
\hline
\end{tabular}

Bahçelerde süs bitkilerinden en fazla gül, zambak, aslanağzı, ağaçlardan da sedir, servi, ardıç, karaçam, meyve olarak da asma ve kayısıya rastlanılmıştır. Bahçelerde yer alan bitkisel materyallere örnekler Şekil 7 'de verilmiştir. Ortak kullanıma açık olan bu alanlarda yetiştirilen bitkilerden herhangi bir gelir elde edilmediği anlaşılmıştır. Bu durum beklenen bir sonuçtur, zira yetiştirilen bitkiler tek bir kişi veya aile için değil toplu konutlarda/sitelerde yaşayan çok sayıda insanın ortak kullanımına açıktır.
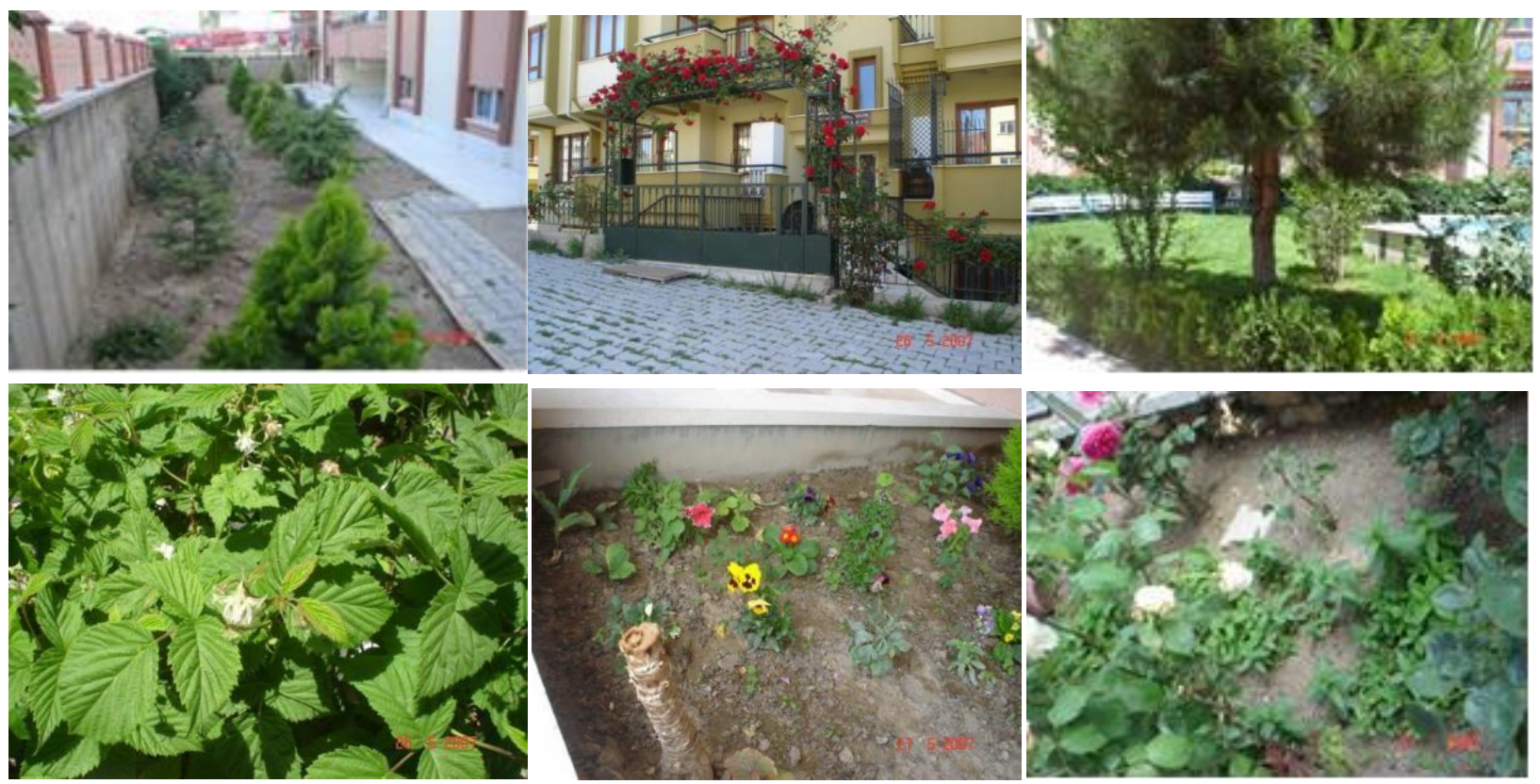

Şekil 7. Bahçelerde rastlanılan bitkisel materyallere örnekler 
Bazı mahallelerde toplu konut/site bahçelerinde kullanılan bitkisel materyaller benzerlik gösterirken bazılarında ise farklılıklar ortaya çıkmaktadır. Örneğin gül anket çalışması yapılan toplu konutların 1 tanesi dışında bütün toplu konut bahçelerinde bulunmaktadır. Yine zambak da 14 toplu konut bahçesinde bulunurken, 9 toplu konut bahçesinde yer almamaktadır. Doğancı, Hızırbey, Sidre, Karaağaç, Sermet, Fatih, Kurtuluş, Turan, Keçeci, Anadolu, Vatan, Ayazmana, Halıkent ve Çünür mahallelerinde olmak üzere toplam 14 toplu konut bahçesinde çim alan mevcuttur. Anket uygulaması ve yerinde ayrıntılı gözden geçirilmesi sonucunda 23 toplu konutun bahçelerinin genel görünümleri incelendiğinde; bahçelerin çoğunda bitkilerin gelişi güzel yerleştirildiği, bazılarında alanın küçük fakat bitki sayısının fazla olduğu görülmektedir. Büyük bahçe alanında az sayıda fakat bitkilerin planlı yerleştirildiği bahçelerin sayısı oldukça azdır. Tablo 6 ve Şekil 8'de toplu konut bahçelerinin genel görünüşleri verilmiştir.

Tablo 6. Toplu konut bahçelerinin bitkisel materyalin genel durumu

\begin{tabular}{|lc|}
\hline Alanın Genel Görünüşü & Seçilme Sayısı \\
\hline Tamamen bitkilendirilmiş & 3 \\
Rast gele bitkiler yerleştirilmiş & 6 \\
Alan küçük, bitki sayısı fazla & 4 \\
Alan büyük, bitki sayısı az & 8 \\
Bitkiler planlı yerleştirilmiş & 6 \\
\hline
\end{tabular}
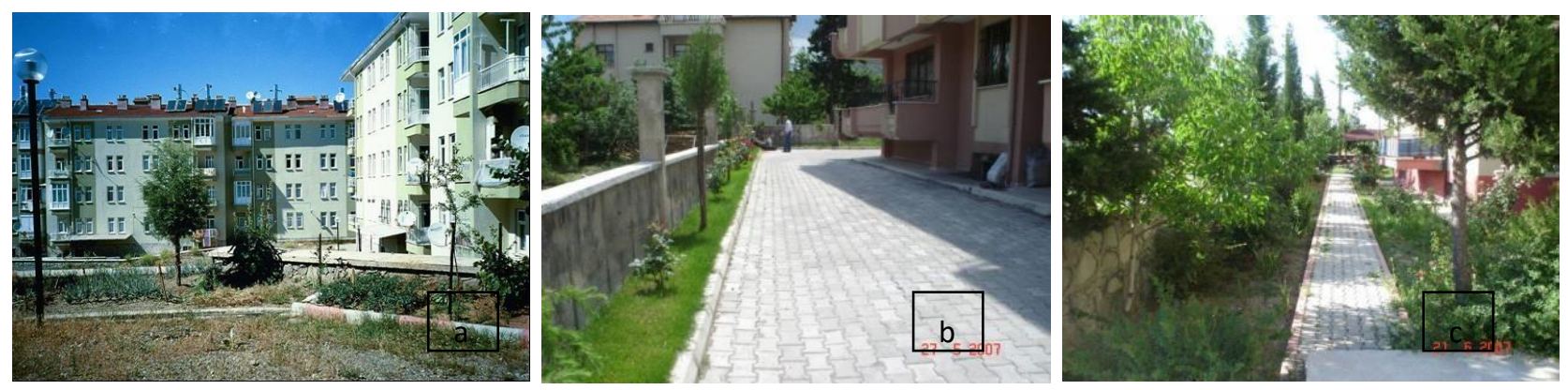

Şekil 8. Isparta kent merkezindeki bazı toplu konut bahçelerinin genel görünüşleri (a: Bahçe alanı geniş, bitki sayısı az toplu konut bahçesi; b: Planlı yerleştirilmiş bitkisel materyaller; c: Yoğun bitkilendirilmiş toplu konut bahçesi)

Toplu konut bahçelerindeki bitkisel materyallerin genel görünüşleri incelendiğinde; üçte birine yakın kısmının bakımlı (\%37), üçte birine yakın kısmının da bakımsız (\%38) olduğu anlaşılmıştır.

Çok katlı apartman bloklardan oluşan toplu konut/site bahçelerinin bazılarının her blok için ayrı ayrı düzenlenmekle beraber büyük çoğunluğunda bahçelerin bir bütün olarak düzenlendiği gözlemlenmiştir. Örnekleri Şekil 9'da verilmiştir.

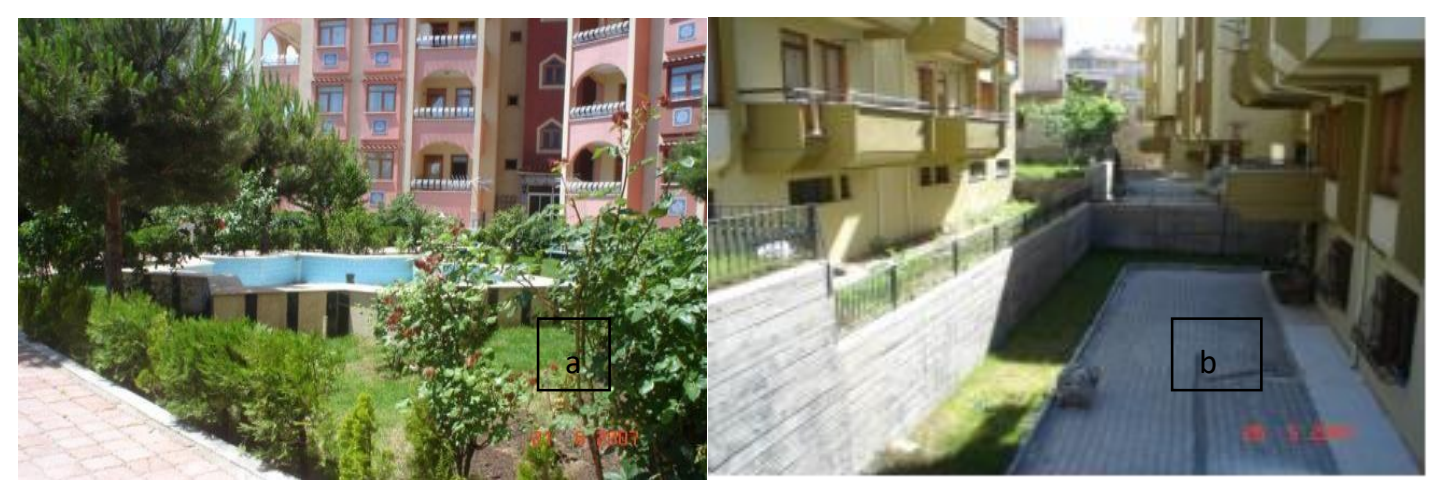

Şekil 9. Bloklar şeklinde (a) ve bütün olarak (b) düzenlenmiş toplu konut bahçeleri 
Kent merkezine yakın mahallelerde yer alan toplu konutların/sitelerin bahçeleri, geniş alanlara sahiptirler. Bu bahçeler, alan bakımından geniş olduğundan, bahçedeki fonksiyon, bitkisel materyal ve içerik bakımından diğer konut türlerinden farklılık göstermektedir. Bu tür bahçelerin düzenlenmesinde gösterilen özen bakımda da gösterilmekte, bu bahçelerin estetik görünüşlerinin süreklilikleri sağlanmaktadır. Bahçelerde ölçü, biçim, doku ve renk açısından bitkisel materyaller ile kompozisyonlar oluşturulmuş, böylece bahçelere hareket kazandırılmış, aynı zamanda bahçeler sakin, huzur verici mekanlar haline dönüştürülmüştür.

Bunun yanı sıra merkeze daha uzak olan mahallelerde ise toplu konutların/sitelerin çoğunda peyzaj tasarım projesi çizdirilmediği için elde edilen her bitki dikilmiş, bu da bahçede karmaşaya neden olmuştur. Konutların geneline bakıldığında, çoğunda bitkilerin rasgele dikildiği, belirli bir plan dâhilinde gerçekleştirilmediği görülmektedir. Çoğunda bitkilerin birbiriyle karışacak şekilde dikildiği; sebzelerin, meyve ağaçlarının ve süs bitkilerinin birbirine karışmış halde olduğu görülmektedir.

Toplu konut/site bahçelerinde de süs bitkileriyle birlikte meyve ve sebzelere de yer verilmiştir. Bu meyve ve sebzelerden özelikle toplu konutlarda/sitelerde ikamet eden site görevlisi yararlanmakta, bunun yanı sira toplu konutlarda ikamet eden diğer kişiler de yararlanmaktadır (Şekil 10).

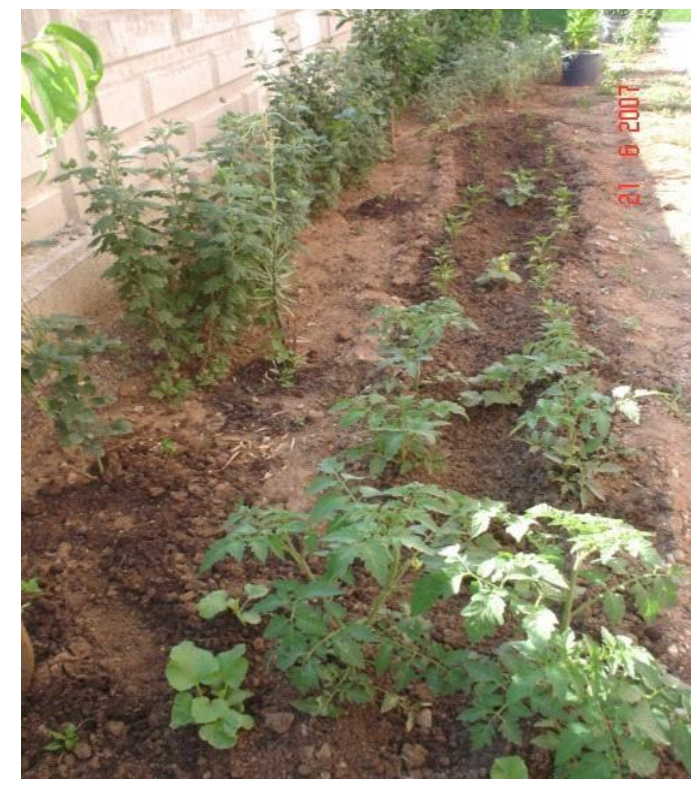

Şekil 10. Sebze bahçesi şeklinde düzenlenmiş toplu konut bahçesi örneği

\section{SONUÇ ve ÖNERILER}

Çalışmada, kentsel yeşil alanların bir birimini oluşturan toplu konutların/sitelerin bahçelerinin günümüzdeki durumları tespit edilmiş, bahçelerindeki kullanımlar ile yapısal ve bitkisel materyal çeşitlilikleri incelenmiştir. Toplu konut oluşumu Isparta kent merkezi için bazı mahalleler dışında henüz yeni olduğundan, bahçe düzenlenmeleri üzerine çok fazla bir benzerlik veya farklılıktan bahsetmek söz konusu değildir. Son yıllarda özellikle kent merkezinde yer alan mahallelerde yoğun toplu konut/site yapımı başlamış ve bu eğilim hala devam etmektedir.

Toplu konutlar/siteler modern planlama ve tasarım ilkeleri ile inşa edildiklerinden, hemen hemen hepsinde belli bir büyüklüğe sahip bahçe alanı tespit edilmiştir. Bu nedenle, bahçelerdeki yapısal ve bitkisel materyaller açısından farklılıklar göze çarpmaktadır. Toplu konutların/sitelerin yoğun olduğu mahallelerde, kişilerin rekreasyonel ihtiyaçlarını karşılamak, aynı zamanda komşuluk ilişkilerini pekiştirmek için ortak kullanım alanları çoğunlukla bu amaca uygun olarak düzenlenmiş, ölçü, biçim, doku ve renk açısından bitkisel donatılar ile kompozisyonlar oluşturularak bahçelere hareket kazandırılmış, böylece bahçeler sakin, huzur verici mekânlar haline dönüştürülmüştür.

Özellikle son yıllarda kırsal alandan kentsel alana yoğun göç nedeniyle Isparta kent merkezindeki bina ve birey sayısı çok fazla artmıştır. Bunun sonucunda da kent merkezinde kentsel açık ve yeşil alanlar ile kişi başına düşen yeşil alan 
miktarı azalmıştır. Toplu konut/site bahçelerinin daha düzenli planlanması, bitki türlerinin seçiminde daha doğru uygulamalar yapılması, bitkilerin fonksiyonel ve estetik özelliklerinin ön plana çıkarılması ile ikamet edenlerin doğaya olan özlemleri azaltılabilir. Bu durum beraberinde kent içi yeşil alanların artmasını da sağlayacaktır. Bunun yanı sıra bahçelerde yetersiz olan yapısal elemanların tamamlanması da bahçelerin daha fazla kullanımını sağlayacaktır.

Yerel yönetimler tarafından toplu konutlar/siteler için en güzel bahçe seçilip ödüllendirilerek kent halkının, bahçesini düzenlemeye teşvik edildiği yarışmalar geleneksel hale getirilmeli, kişiler bu tür etkinliklere yönlendirilmelidir. Modern çağın bir gereği olarak Belediye sınırları içindeki konut alanlarının inşaat ruhsatı verilmeden önce onaylı çevre düzenleme projesi (peyzaj projesi) de zorunlu kılınmalıdır.

Konut ve çevresindeki yaşam koşulları, insanın psikolojik ve sosyal gelişimini etkilediğinden, sağlıklı toplumlar oluşturabilmek için kullanıcıların gereksinmelerini karşılayan, nitelikli ve sağlıklı yaşam çevreleri oluşturulmalıdır. $\mathrm{Bu}$ bağlamda, toplu konutların/sitelerin bahçelerinin daha profesyonel yaklaşımlarla peyzaj mimarları tarafından tasarlanması ve uygulanması, bakımlarının eğitimli kişiler tarafından yapılması, mekanların prestij, işlevsellik ve sürdürülebilirliğinin arttırılması açısından daha uygun olacaktır.

\section{Etik Standart ile Uyumluluk}

Çıkar Çatışması: Yazarlar herhangi bir çıkar çatışmasının olmadığını beyan eder.

Etik Kurul İzni: Bu çalışma için etik kurul iznine gerek yoktur.

Finansal Destek: Bu çalışma, SDÜ Rektörlüğü Bilimsel Araştırma Projeleri, 1370 - D - 06 No'lu “'Isparta Kent Merkezi Konut Bahçelerindeki Bitkisel Materyalin İncelenmesi Üzerine Bir Araştırma" başlıklı proje kapsamında gerçekleştirilmiştir.

\section{KAYNAKÇA}

Anonim, 1. Isparta genel bilgiler. https://ispartada.gen.tr/isparta-genel-bilgiler. Erişim tarihi: Mayıs, 2020.

Anonim, 2. Isparta Ili ve çevresi haritası. https://www.lafsozluk.com/2009/03/isparta-ilinin-ilceleri. Erişim tarihi: Mayıs, 2020.

Anonim, 3. Isparta ilinin iklimi. https://isparta.ktb.gov.tr/TR-71025/iklim.html. Erişim tarihi: Mayıs, 2020.

Atakan Öznam, B. (2013). İstanbul'da Kamu Kontrolünde Yaptırlan Toplu Konut Alanlarının Yeşil Alan Kriterleri Açısından Değerlendirilmesi: Ataşehir-Esenkent-Halkalı Örnekleri. İstanbul Üniversitesi Orman Fakültesi Dergisi, vol.63, 19-26.

Atala, Ç. (2002). Bursa Beşevler Bölgesi'ndeki Konut Yerleşimlerinin Performans Analizi, Gazi Üniversitesi, Fen Bilimleri Enstitüsü, Yüksek Lisans Tezi, Ankara.

Demir, E. (1998). Kentsel Farklılaşma ve Kimlik: Ankara'da Konut Çevreleri Üzerine Bir Araştırma. Ankara Üniversitesi Sosyal Bilimler Enstitüsü Kamu Yönetimi ve Siyaset Bilimi Anabilim Dalı Kent ve Çevre Bilimleri Dal, Doktora Tezi, 195s, Ankara.

Dönmez, Y., Özyavuz, M., Gökyer, E. (2015). Safranbolu Kentinin Konut ve Site Alanlarının Yeşil Alan Durumlarının Saptanması. İnönü Üniversitesi Sanat Ve Tasarım Dergisi. Cilt/Vol. 5 Sayı/No.11: 1-12.

Giritlioğlu, C. (1991). Şehirsel Mekan Ögeleri ve Tasarımı I. İTÜ Kütüphanesi Sayı: 1459, İTÜ Mimarlık Fakültesi Baskı Atölyesi, İstanbul.

Orhon, İ. (1987). Toplu Konut İşletmesi III, TÜBİTAK, s:5. 
Özyavuz, M., Dönmez, Y. (2016). Konut ve Site Alanlarında Uygulanan Peyzaj Tasarımlarının Yeterliliği Üzerine Bir Araştırma: Tekirdă̆ Örnĕ̆i. Düzce Üniversitesi Ormancılık Dergisi Cilt:12, Sayı:2, S:108-122.

Yücedağ, C., Kaya, L.G., Ulu, A. (2017). Burdur Kenti Toplu Konut ve Site Alanlarının Peyzaj Tasarım Yeterliliğinin Íncelenmesi. Mehmet Akif Ersoy Üniversitesi Fen Bilimleri Enstitüsü Dergisi 8(2): 114-122.

Yüksel, D.Y., Aydınlı, S., Pulat, G. (1996). Toplu Konut Uygulamalarında Niteliksel Değerleri Araştırmaya Yönelik Bir Çevre Analizi. Cilt 1, Konut Araştırmaları Dizisi 4, Toplu Konut İdaresi Başkanlığı, ODTÜ Basım İşliği, Ankara. ISBN 975-19-1330-6. 